\section{DIFFUSED INNOMINATE ANEURYSM.}

By J. G. BLACKMAN, M.D. BREX., M.R.C.S., \&c.

THE great interest and importance attaching to aneurysmal disease of the innominate artery, and its comparative rarity, induce me to record the following case, which $I$ think particularly shows the impossibility of diagnosing the actual limits of the disease in this class of cases, and the risk in operating lest the available vessels be atheromatous.

William W-, aged sixty, shipwright, first came under my care four years ago, suffering from hæmorrhoids. As he was losing a rather large quantity of blood after each stool, and was much weakened in consequence, I proposed their removal to him, to which procedure he assented. Upon examining his heart preliminary to the administration of an anæsthetic, a somewhat loud systolic bruit was heard over the aortic area. To be on the safe side it was decided to operate without anæsthesia, which was accordingly done, and the patient made a quick recovery.

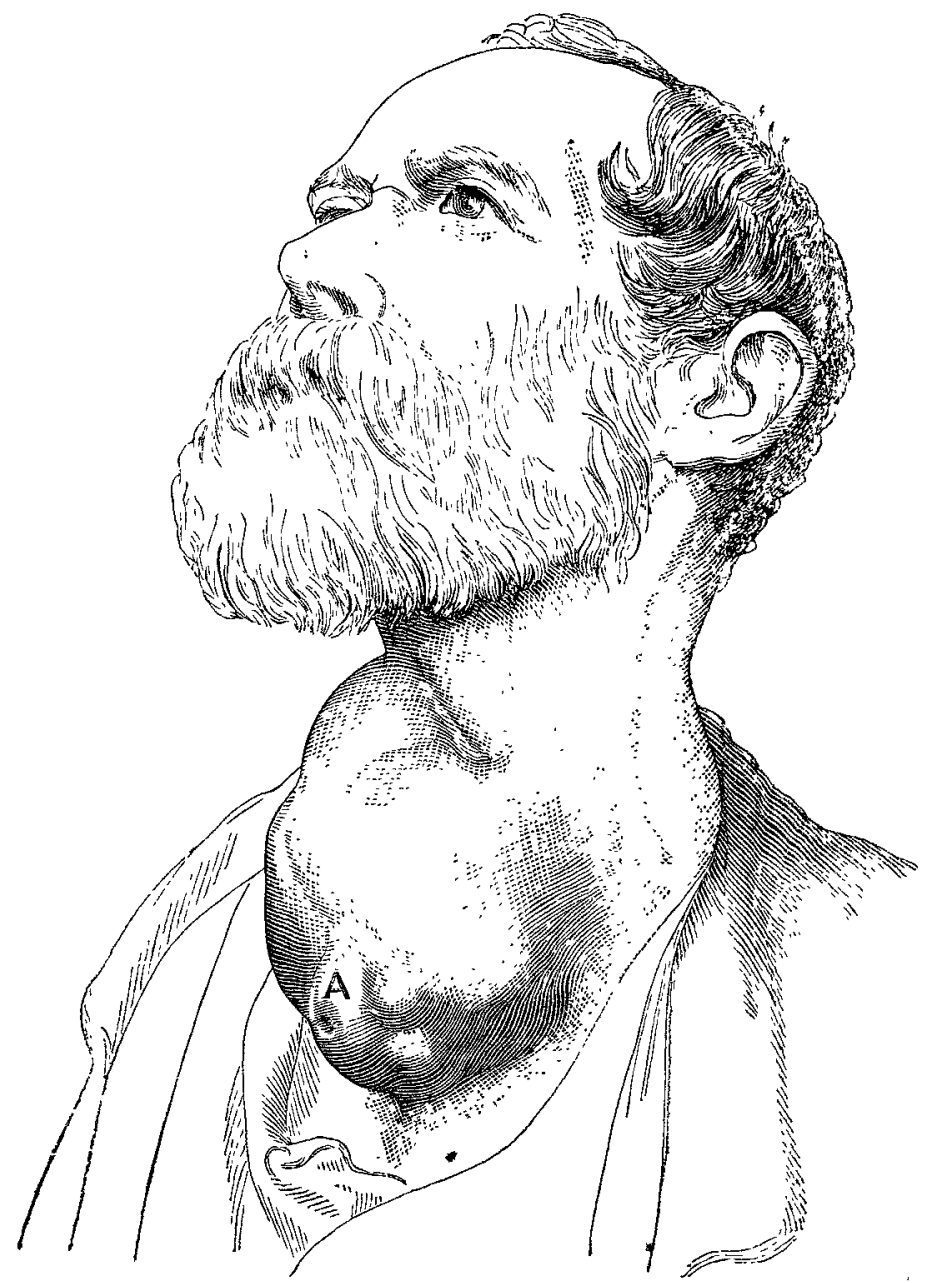

He, however, shortly afterwards again consulted me, complaining of obscure pains in the chest and back, which he said quite unfitted him for his work; and in accordance with his wish the authorities of the dockyard granted his superannuation. On examining his chest again, I could discover nothing abnormal except the bruit previously mentioned, and the subjective symptoms seemed quite out of proportion to the objective. I was, however, able to afford him some relief by the administration of anodyne drugs, and after a time I quite lost sight of him. This respite was, however, not destined to last long, for in November, 1885, he once more came to me, this time complaining of a swelling in the neck in addition to his other troubles. On examination, I discovered a pulsating tumour, the size of a large walnut, situated immediately behind the right sterno-clavicular joint. He did not complain of much pain. The right radial pulse was full and strong, while the left was small and weak. The right carotid pulse was weakened. In spite of the anomalous condition of the radial pulses, I felt sure I had to deal with an innominate aneurysm, probably complicated with aortic disease. I saw him in consultation with several medical friends, who, with myself, deemed operative interference unadvisable, considering the probable general diseased condition of his arteries, and also the possibility of its being aortic. I prescribed a spare diet with absolute rest, and gave a mixture containing iodide of potassium with morphine. The second injunction he refused to obey, and persisted, in spite of repeated warnings, in taking long walks and occasionally doing a little gardening. Under these adverse circumstances the tumour steadily increased until about three months before his death, at which period it began suddenly to enlarge very rapidly, and at each visit I noticed a decided difference. The dimensions it attained are well shown in the accompanying woodcut, which is from a photograph taken a month before death by Mr. Newby, F.R.C S. Eng. It will be noticed that the surface is very uneven, and appeare, as it were, "pointing" in several places, one of which (marked A) became very thin. and developed a black crust on its summit, which eventually came off leaving an ulcer, the base of which seemed to be entirely composed of cellular tissue. This condition caused me great anxiety, as it gave one the idea that the next pulsation must burst the apparently thin tissue. Fortu= nately this event did not happen, for although the ulcer spread to the size of a florin and bled to a trifling extent, it gradually became drier, and the poor fellow died from exhaustion, and in part possibly from suffocation, on Dec. 7th 1886, having only taken to his bed during the last week of his long illness.

Necropsy. - The wall of the sac was of varying thickness, being at the most not more than from three-eighths to half an inch, and in some places was extremely thin. The arterial coats could not be distinguished, and there was scarcely any attempt at lamination. A small clot of fibrine was found in the interior, surrounded with dark, semicoagulated blood. On tracing the sac, it was found to pass in all directions. To the outer side, it communicated with the right subclavian artery, and upwards with the carotid artery of the same side; whilst to the inner side it passed across the trachea, œesophagus, left carotid, and subclavian arteries. Downwards, it had passed over the clavicles and sternum, eroding the sternal ends of the former bones and the upper part of the first piece of the latter bone. Backwards, it had pressed upon and displaced both the trachea and the œsophagus. The aorta was found to be considerably dilated and atheromatous, the disease involving the whole of the arch and the commencement of the thoracic portion. On passing the finger along the interior of this vessel, one discovered the opening corresponding to the innominate artery, which communicated directly with the aneurysmal sac; the atheroma here appeared to be less marked. Passing the finger along still further, the openings of the left carotid and subclavian arteries could be made out, the former being a mere chink, whilst the latter was of natural size. Both openings were, however, rigid, and surrounded by atheromatous calcification, and gave the impression of being foramina in bone. The coats of both carotias and subclavians were more or less diseased. A further inspection was not permitted by the friends.

Portsmouth.

\section{MALIGNANT DISEASE OF RIGHT LUNG AND POSTERIOR MEDIASTINUM, PRO-} DUCING COMPLETE PARAPLEGTA.

BX FREDERICK J. SMITH, M.R.C.P., M.B. OxON., NEDICAL REGISTRAR TO THE LONDON HOSPITAL.

Br the kindness of Dr. H. G. Sutton, under whose care the patient was in hospital, I am enabled to publish the following case, which presents somewhat rare and peculiar features.

B. C_- aged forty-five, was admitted into the London Hospital on June 1st, 1886, complaining of pain in the right side and numbness of the legs. Family history very good. He has been engaged as stevedore and coal-porter all his life, and until three years ago had always enjoyed good health. Is a moderate drinker, never exceeding three pints of beer a day. Three years ago he had severe pain in the chest and slight cough, and is said to have been treated for pleuro-pneumonia. Ever since then he has had pain in the 
right side, and latterly, he says, the lower part of the abdomen and lower extremities have felt numbed.

Condition m admission.--Looks well, but is of a melancholy disposition, and cannot sleep on account of the pain. $\mathrm{He}$ states that he perspires freely, but not on the right side. Digestive system fairly good. Respiratory system: Has a slight cough; physical signs normal, except at right base, where there is dulness, deficient breath sounds, increased vocal fremitus, and pain on movement. Vascular system healthy. Nervous system: Knee jerks equal, and not remarkable; plantar and other superticial reflexes present, and about normal in freedom. The patient does not seem fully cognisant of sensations of heat, cold, and pain. Able to walk, but not well.

The following is a short abstract of the daily notes from the date of the patient's admission until his death:June 7th: Unable to pass urine; when drawn, found to be alkaline; complains of much pain in the bladder; cannot stand without support.-16th: Passed a motion involuntarily; knee jerks exaggerated ; unable to move either leg.21st: Entirely unconscious of lower extremities.-30th : Legs contracted; commencing gangrene of right heel.-July 19th: Since last note, pain in right side and also pain referred to legs have been the chief symptoms.-22nd: Gland projects at inner end of right clavicle; a bedsore has formed, and is extending rapidly; right leg very sensitive; temperature very variable.-Nov. 1st: In this interval the chief notes are a progressive loss of strength, and complaints of pain in chest, together with a most distressing cough.29th: Pain of a girdle character and in left side very distressing:-Dec. 14th : Troubled with "fits" and fainting.Jan. 12th, 1887 : Continued to get weaker, and died quietly without any further definite symptoms.

Necropsy.-Body much wasted. On opening the thorax, a large mass was at once apparent, occupying the right upper part of the posterior mediastinum. On further exploration it was found that the new growth had extended into the base of the right lung in a downward direction; upwards, it had infiltrated the glands of the posterior mediastinum, thus producing the bulging above the right clavicle; backwards, it was found to have softened and infiltrated the bodies of two or three of the upper dorsal vertebræ, and to have compressed the spinal cord to such an extent as to have almost obliterated it opposite the fourth dorsal vertebra, with complete softening above and below this point for some little distance. The growth had apparently begun in the neighbourhood of the right bronchus, as here it had softened down into a mass of cheesy, purulent material. The kidney showed acute pyelitis, and the bladder evidence of cystitis. The other organs presented only such changes as might fairly be attributed to the mode of death. The naked-eye appearances of the growth showed that it was an encephaloid, or soft cancer, with much juice and very little fibrous stroma.

Remarks.-The above case is interesting from one or two points of view. Primary cancer of the lung (be it remembered that so careful an observer as Dr. H. Sutton performed the post-mortem examination, and found no other cancerous deposit) is in itself a somewhat rare affection, and it must be rarer still to find examples of a soft cancer in such an important organ as the lung which took three years to kill. I say three years, for unless we take the illness of three years ago to have been the commencement of the growth we have no other possible explanation of its origin. Clinically, the case was one of extreme interest, owing to the difficulty of diagnosis. On admission the signs in the lungs were such as to give one no clue whatever as to the dangerous nature of the case, nor did the nervous phenomena lend us much aid, for, though the paraplegia was somewhat marked, the signs of spinal cord disease were absent or ill-defined. After a week's stay in hospital, however, the signs of acute myelitis rapidly developed, and then, indeed, the case assumed a most serious aspect. But still the diagnosis was anything but absolutely certain, and not till the end of July, when the enlarged gland appeared above the clavicle, could an almost positive conclusion be drawn as to the nature of the case. 1 can find no mention in ordinary text-books of this particular cause of paraplegia and myelitis-i.e., growth from the lung. I presume the reason is that such growths usually kill before spreading in that direction. The growth appeared not to have infiltrated the cord at all, but merely to have compressed it. I regret to say that a microscopical examination has not been made.

Westrstreet, Finsbury-circus.

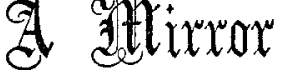

\author{
HOSPITAL PRACTICE, \\ BRITISH AND FOREIGN.
}

Nulla autem est alia pro certo noseendi via, nisi quamplurimas et morborum et dissectionum historias, tum aliorum tum proprias collectas habere, et inter se comparare.-MORGAGNI De Sed. et Caus. Morb. lib. iv. Proœmium.

\section{HOSPITAL FOR SICK CHILDREN, GREAT ORMOND STREET.}

CASE OF SUPRA-PUBIC IITHOTOMY; HAMORTHAGE INTO THE BLADDER ; RECOVERY ; REMARKS.

(Under the care of Mr. J. H. MoRGAN.)

Numerous instances of successful operation for the removal of calculus by incision into the bladder above the pubes have been recorded during the last few months. The following case, however, is one in which an unusual complication occurred during treatment, and the account of it, with the remarks of Mr. Morgan, and his explanation of the mode of occurrence of the hæmorrhage, will be read with interest. For the notes of the case we are indebted to Dr. Penrose.

W. G-- a boy, aged six years and a quarter, of healthy aspect, and with no history of previous illness, was brought to the hospital on account of passing blood with his urine, and of pain in micturating. This had existed for two years. Eight months previously he had been circumcised at another hospital. The boy had always lived in London. The mother's family was gouty. The pain and blood followed micturition, and both were worse after exercise. The patient had to rise at night to pass urine. The urine after admission was slightly alkaline, without any albumen. A stone was detected on sounding, which it was decided to remove by the supra-pubic operation.

The patient having been placed under chloroform, a small gum catheter was passed and the bladder emptied of urine; it was then filled with a moderate quantity of boracic lotion, the catheter plugged, and an indiarubber band placed round the penis to avoid leakage by the side of the catheter. A tampon was passed into the rectum and distended with air until the bladder could be seen in outline upon the abdominal surface projecting with moderate prominence. An incision about an inch and a half from just above the symphysis was made in the middle line and the dissection carried down to the fat overlying the bladder, in which one vessel was tied before division. The wall of the bladder being exposed, it was incised, the finger passed in, and the stone immediately detected. This was of moderate size, and was extracted with the aid of forceps. The muscular coat of the bladder was then sewn up by inserting a number of separate fine catgut sutures, the mucous coat being avoided. The wound in the abdominal wall was then united by silk sutures and a small horsehair drain inserted at the lower angle. The stone was composed of uric acid. The catheter was allowed to remain in the bladder.

On the following day the wound, which was dressed antiseptically, looked perfectly quiet. The boy was well, and the temperature normal. Urine, slightly blood-stained, passed through catheter. On the second day the catheter was removed, as it was causing some urethritis, and urine was passed per urethram. The drain from the wound was also removed. On the third day the patient was restless, and complained of pain. The quantity of urine passed was small, and was slightly stained with blood. More was drawn off by catheter. There was a good deal of straining, and, thinking that this might be due to constipation, an enema was administered by the house-surgeon. Pain increased; no sleep. Ordered two minims of tincture of opium. Temperature normal. On the fourth day after the operation, the patient was pale, and the surface cold. The bladder was seen and felt distended up to the umbilicus, hard and tense, but not tender. To relieve this, which was evidently due to the presence of blood, a catheter was passed, and some warm boracic lotion injected. This was repeated several times, the instrument when withdrawn being filled with clotted blood, the fluid dribbling away mixed with blood. The boy slept between three and four hours. 